\title{
Albino clutch of moor frog Rana arvalis - a rare observation from Poland
}

\author{
Mikołaj KACZMARSKI and Jan M. KACZMAREK \\ Institute of Zoology, Poznan University of Life Sciences, Wojska Polskiego 71 C, 60-625, Poznań, Poland; \\ e-mail: traszka.com@gmail.com
}

\begin{abstract}
Moor frog Rana arvalis is widespread in Poland and its geographic range spans from Central Europe up to Siberia, but any records of albinism are rare in the species. Freshly laid albino spawn of moor frogs was observed during nocturnal fieldwork near the village of Lubosz, north-western Poland, in spring 2016. We noted the further development of eggs, but no albino tadpoles nor metamorphs were found later during the season. Both albinism and transient albinism have been noted in the species, this being the first observation from Poland. Atypical pigmentation impairs cryptic function of body colouring and might affect survival. The observation comes from a large frog population in a relatively undisturbed habitat, and thus it adds to the body of literature concerning the background level of abnormalities in amphibian populations.
\end{abstract}

Key words: Anura, eggs, albinism, colour mutation, Ranidae, transient albinism

\section{INTRODUCTION}

While limb or body malformations are widely discussed in the herpetological literature (Blaustein \& Johnson 2003, Skelly \& Bernard 2010, Peltzer et al. 2011), colour anomalies received less attention, with only few papers dealing with them in a more complex and detailed way (Jablonski et al. 2014, Henle et al. 2017a, Henle et al. 2017b). In general, anomalies are often detected in strongly anthropogenically modified environments, like agricultural or urban habitats, and to much lesser extent in less altered habitats like natural wetlands or forests (Peltzer et al. 2011). Henle et al. (2017b) argues that the number of the detected cases of anomalies in amphibians increased in the second part of the 20th century, probably due to environmental pollution, but reliable data are still lacking.

Pigmentation anomalies are observed in urodeles (Busack \& Donaire 2014; Jablonski et al. 2014) as well as anurans (Pabijan et al. 2004; Jablonski et al. 2014; Henle et al. 2017b; Kolenda et al. 2017). Numerous cases of albinism were described in the Eurasian genus Pelophylax (Pabijan et al. 2004). Within the members of the genus Rana native to Poland, observations of albino individuals include the common frog Rana temporaria (Linnaeus, 1758) (Zuiderwijk 1990) and the moor frog Rana arvalis (Nilsson, 1842) (Klemz \& Kuhnel 1986; Maštera et al. 2015). The latter species is also known to exhibit the so-called 'transient albinism' (Henle et al. 2017b), where tadpoles developing from atypically white eggs gradually acquire pigmentation during development (Henle et al. 2017a). The species also shows a large variation in body colour, with three colour morphs observed in Poland, i.e. typical (var. typica), striped (var. striata), and spotted (var. maculata) (Rybacki 2008). The geographic range of the moor frog spans from Central Europe up to Siberia (Kuzmin et al. 2016). The species is widespread in Poland, reaching elevations over 850 m a.s.l. (Rybacki 2008, Majtyka \& Ogielska 2012). 


\section{OBSERVATION}

Freshly laid albino (white) spawn of moor frogs was observed during a night visit in a mass breeding site near the village of Lubosz, northwest Poland $\left(52,545356^{\circ} \mathrm{N}, 16,213132^{\circ} \mathrm{E}\right)$ on 29 March 2016 (Fig. 1). In the following days (31 March 2016) the development of eggs was observed, but no albino tadpoles nor metamorphs were noted later during the season (13 April 2016, 17 April 2016). The breeding site is very large, with the flooded area of over 3 hectares and the number of clutches laid estimated for over a 1,000. The site consists of a temporarily flooded meadow, a ditch and an alder forest. The breeding site borders with cultivated fields. During the frog breeding season, the whole area of the meadow, ditch and forest were submerged.

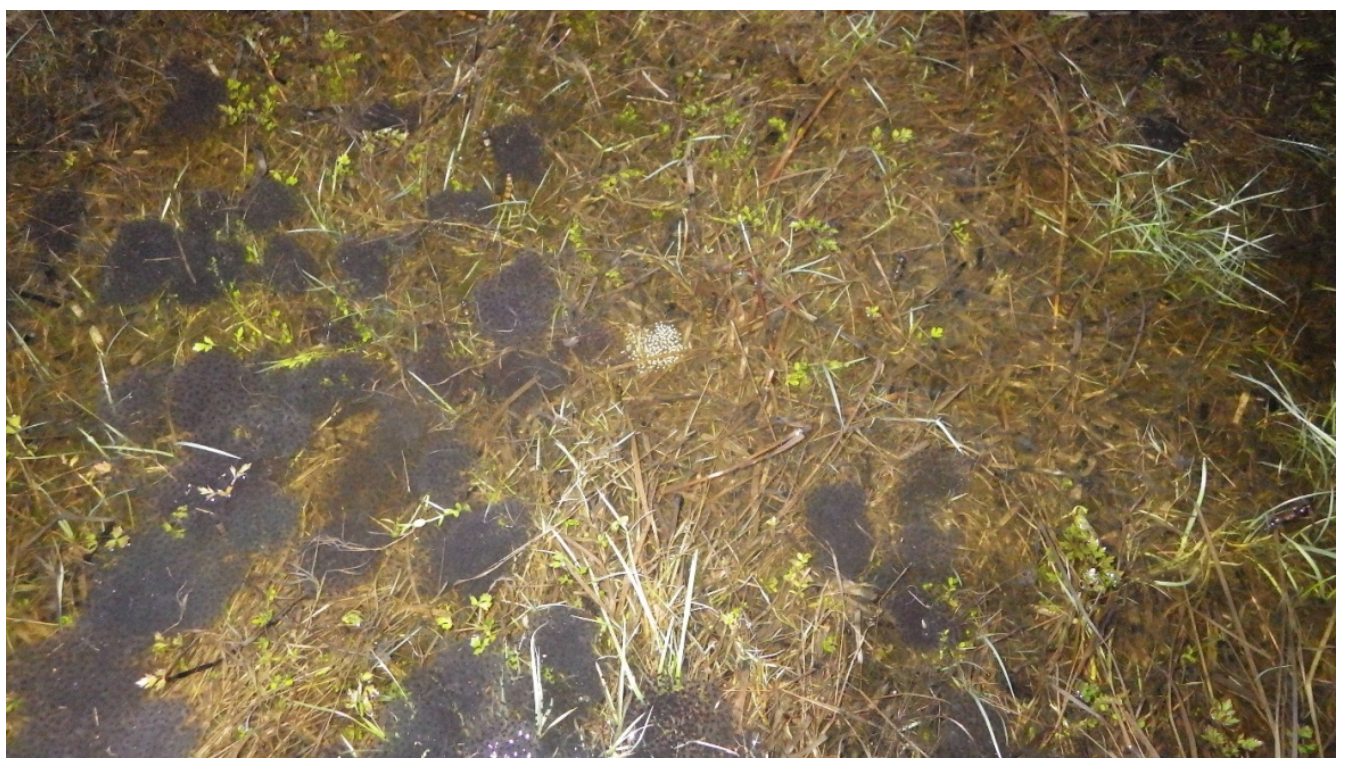

Fig. 1. Albino clutch of moor frog Rana arvalis (Nilsson, 1842) observed near the village of Lubosz, northwest Poland on 29 March 2016.

\section{DISCUSSION}

Similar observations were published from northern Germany (Berlin: Klemz \& Kuhnel 1986), central Czech Republic (near the village of Pávov - Vysočina Region: Maštera et al. 2015), and near the border of Europe and Asia (Ekaterinburg in Russia: Henle et al. 2017b). According to Pabijan et al. (2004), in Pelophylax frogs albino individuals develop from such atypically coloured eggs. However, Henle et al. (2017a) introduce the term 'transient albinism', where tadpoles that hatched from the white eggs increasingly acquire pigmentation during the larval stages. Such cases were been described for several amphibian species, including $R$. arvalis, and are usually described from single egg clutches (Henle et al. 2017b), just as in our observation. In amphibians, the vast majority of cases of albinism origin from single, recessive mutations (Henle et al. 2017b and references therein). Pigmentation anomalies might affect fitness of individuals (Jablonski et al. 2014). Atypical pigmentation impairs cryptic function of body colouring and might affect survival (Busack \& Donaire 2014, Rojas 2017). Individuals with any colour aberrations are easily spotted by predators and are usually eliminated (Andrén \& Nilson 1981). That is why their observations are relatively rare in natural environment 
compared to caged populations (Pabijan et al. 2004). Interestingly, numerous observations of albino individuals come from urban areas (Bionda et al. 2012, Busack \& Donaire 2014, Jablonski et al. 2014). This could be attributed to higher detectability of atypical individuals in urban areas. For example, in North America the most common urban species dominate in historical reports concerning albino birds (Gross 1965). On the other hand, amphibians are susceptible to loss of genetic diversity in urban and farming landscapes due to reduced gene flow between populations isolated by roads and developments (e.g. Johannson et al. 2005, Mikulíček \& Pišút 2012), therefore both higher detectability and reduced heterozygosity could affect incidence of albino individuals in urban amphibians. In the case discussed, the breeding site borders with intensively managed crop fields (wheat, corn, oilseed rape) that are likely to be treated with agrochemicals, which are suggested to be one of the factors driving the emergence of anomalies in amphibians (Henle et al. 2017b). However, we argue that the their potential effect was rather limited: the breeding pond catchment consisted mainly of forests, and the timing of breeding activity did not coincide with the use of most pesticides.

Albinism is one of the most frequently reported examples of colour abnormalities in amphibians, with background rates up to $1 \%$ also in large, seemingly healthy populations (Henle et al. 2017, and references therein). Low incidence of abnormal clutches (one in approx. 1,000 , i.e. $\approx 0.1 \%$ ) suggest that our observation remains within such a background rate of anomalies, and adds to the growing body of research on anomalies observed in natural conditions.

\section{ACKNOWLEDGEMENTS}

The authors are grateful to A. M. Kubicka and J. Kloskowski for their help in the field and valuable comments during the preparation of the manuscript.

\section{REFERENCES}

ANDRÉN C. \& NILSON G. 1981. Reproductive success and risk of predation in normal and melanistic colour morphs of the adder, Vipera berus. Biological Journal of the Linnean Society 15: 235-246.

Bionda C. L., SAlAs N. E., CARAFFA E., BARAQUET M. \& MARTINO A. L. 2012. On abnormalities recorded in an urban population of Rhinella arenarum from central Argentina. Herpetology Notes, 5: 237-241.

Blaustein A. R. \& Johnson P. T. 2003. The complexity of deformed amphibians. Frontiers in Ecology and the Environment 1: 87-94.

Busack S. D. \& Donaire D. 2014. Albinism in Pleurodeles waltl. Boletín la Asoc Herpetológica Española 25: 12-14.

GROSS A. O. 1965. The incidence of albinism in North American birds. Bird Banding 36: 67-71.

Henle K., Duboise A. \& Vershinin V. 2017a. Commented glossary, terminology and synonyms of anomalies in natural population of amphibians. In: Studies on anomalies in natural populations of amphibians. Mertensiella 25: 9-48.

Henle K., Duboise A. \& Vershinin V. 2017b. A review of anomalies in natural populations of amphibians and their potential causes. In: Studies on anomalies in natural populations of amphibians. Mertensiella 25: 57-164.

JABlOnSKi D., ALENA A., VlCEK P. \& JANDZIK D. 2014. Axanthism in amphibians: A review and the first record in the widespread toad of the Bufotes viridis complex (Anura: Bufonidae). Belgian Journal of Zoology 144: 93-101.

Johansson M., Primmer C. R., SAHLSTEIN J. \& MERILA J. 2005. The influence of landscape structure on occurrence, abundance and genetic diversity of the common frog, Rana temporaria. Global Change Biology 11: 1664-1679.

Kolenda K., NAJBAR B., NAJBAR A. KacZMAReK P., KacZMARSKi M. \& SKAWIŃSKi T. 2017. Rare colour aberrations and anomalies of amphibians and reptiles recorded in Poland. Herpetology Notes 10: 103-109.

KlemZ C. \& KuHNEL K. D. 1986. Ein Beitrag zum Albinismus beim Moorfrosch Rana arvalis NiLSsON, 1842 (Salientia: Ranidae). Salamandra 22: 190-195.

Kuzmin S., Tarkhnishvili D., Ishchenko V., Tuniyev B., Beebee T., Anthony B. P., Schmidt B., Ogrodowczyk A., Ogielska M., Babik W., Vogrin M., Loman J., Cogalniceanu D., KovÁcs T. \& Kiss I. 2016. Rana arvalis. The IUCN Red List of Threatened Species. Available at: http://www.iucnredlist.org/ e.T58548A86232114 (12 July 2017)

MAJTYKA T. \& OgIELSKA M. 2012. Żaba moczarowa Rana arvalis. In: MAKOMASKA-JUCHIEWICZ M. \& BARAN P. (eds), Monitoring gatunków zwierząt. Przewodnik metodyczny. 3. Główny Inspektorat Ochrony Środowiska, Warszawa. 435-449 pp. 
MAŠTERA J., ZAVADIL V. \& DVOŘÁK J. 2015. Vajička a larvy obojživelniků. České republiki. Academia, Praha. 180 pp.

MiKulíčEK P. \& PIŠÚT P. 2012. Genetic structure of the marsh frog (Pelophylax ridibundus) populations in urban landscape. European Journal of Wildlife Research 58: 833-845.

Pabijan M., CZARniewsKa E. \& Berger L. 2004. Amelanistic phenotypes in Western Palearctic water frogs from Poland (Anura: Ranidae: Rana). Herpetozoa 17: 127-134.

Peltzer P. M., Lajmanovich R. C., Sanchez L. C., Attademo A. M., Junges C. M., Bionda C. L., Martino A.F. \& BASSO A. 2011. Morphological abnormalities in amphibian populations from the mid-estern region of Argentina. Herpetological Conservation Biology 6: 432-442.

RoJAs B. 2017. Behavioural, ecological, and evolutionary aspects of diversity in frog colour patterns. Biological Reviews 92: 1059-1080; DOI: 10.1111/brv.12269

RYBACKI M. 2008. Distribution, morphology, ecology and status of the moor frog (Rana arvalis) in Poland. Zeitschrift für Feldherpetologie Supplement 13: 231-248.

SKelly D.K. \& BenARD M.F. 2010. Mystery unsolved: Missing limbs in deformed amphibians. Journal of Experimental Zoology Part B: Molecular and Developmental Evolution 314: 179-181.

ZUIDERWIJK A. 1990. Albinisme bij Rana temporaria: een witte Bruine kikker. Lacerta 52: 68-69. [In Dutch]

\section{STRESZCZENIE}

\section{[Albinotyczny skrzek żaby moczarowej - rzadka obserwacja z Polski]}

Żaba moczarowa Rana arvalis jest rozpowszechnionym w Polsce gatunkiem. Jej geograficzny zasięg obejmuje szeroki obszar od Europy Środkowej po Syberię jednak mimo to opisane przypadki albinizmu są rzadkie. W naszej pracy prezentujemy przypadek wykrycia świeżo złożonego skrzeku żaby moczarowej o atypowym wybarwieniu. Skrzek wykryto podczas nocnych badań terenowych prowadzonych wiosną 2016 w pobliżu wsi Lubosz, w północno zachodniej Polsce. W kolejnych dniach odnotowano rozwój skrzeku, jednak po rozpłynięciu się kijanek nie wykryto osobników ubarwionych albinotycznie. Zgodnie z literaturą atypowe ubarwienie (albinizm lub albinizm przejściowy) wpływa na funkcjonowanie organizmu, może mieć także wpływ na przeżywalność. Obserwacja pochodzi z dużej populacji żab zasiedlających stosunkowo niezakłócone środowisko, jednocześnie jej częstość mieści się w obrębie naturalnie występującej zmienności. Tego typu obserwacje są stosunkowo rzadkie w warunkach naturalnych jednak naszym zdaniem wymagają większej uwagi. 